\title{
The Influence Of Job Stress \\ On The Components Of Organisational Commitment Of Health Care Personnel In The Eastern Cape Province South Africa
}

\author{
Vongai Sarah Ruzungunde, University of Fort Hare, South Africa \\ Chan Murugan, University of Fort Hare, South Africa \\ Clifford K. Hlatywayo, University of Fort Hare, South Africa
}

\begin{abstract}
Health care personnel are often exposed to strenuous working conditions due to their nature of work. The study assessed whether job stress affects the organisational commitment of employees within the health institutions. A quantitative design was used; the sample consisted of 141 respondents from selected public health institutions within the Nkonkobe Municipality Region, Eastern Cape, South Africa. Cluster sampling was used to select the hospitals and then the simple random sampling was used to select the sample from the cluster. Pearson Correlation Analysis was used to solicit the sought relationships. Results of the study showed significant relationships between job stress and organisational commitment showing that job stress has an effect on the commitment of workers. These findings are helpful and useful to the health department in implementing policies and procedures that will reduce job stress in employees in order to ensure that high levels of commitment towards the organisation are maintained for optimal success.
\end{abstract}

Keywords: Job Stress; Work Stress; Organisational Commitment; Health Employees

\section{INTRODUCTION}

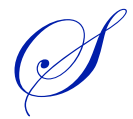

tress occurs when an individual is faced with an opportunity that he/she desires but which carries uncertain outcomes yet it is of great importance to them (Robbins \& Sanghi, 2006). It affects us differently thus Yahaya, Yahaya, Ma'alip, Ramli, and Kamal, (2012) view it as subjective. Stress is a great contributor to decreased organisational performance, low quality in the presentation of work and absenteeism arising from stress related health problems, among many other reasons (Yahaya et al., 2012; Iqbal, Ehsan, Rizwan \& Noreen, 2014).

Health care employees work in an environment which exposes them to stressfulconditions. They work long hours; subject to overtime and work on weekends; leaving them with little time for personalendeavours (Nomaguchi, 2009; Crouter, Head, McHale \& Tucker, 2004). These employees also face heavy workloads, low professional prominence, difficulties in relating within the workplace, medical inflation, overcrowded hospitals and difficulty in the accomplishment of the roles, amongst other challenges (McNeely, 2005; Hall, 2004). Public health care employees, in the developing world, face much worse conditions as they deal with numerous patients and usually work under sourced and overcrowded environments and yet they are expected to perform to the best of their abilities. Pressure mounts on health care employees when they try to maintain and balance the roles of work and family.

When this balance is not well managed it results in a decline in performance; high turnover and absenteeism. If not managed well occupationalstress will affect one both physically and emotionally (Jamal, 2005; Yahaya et al., 2012). These are evident in employees experiencing job stress and these both diminish the quality of care provided by the employees (Hall, 2004; Bakker \& Leiter, 2010). Stress is an area of concern for employers and employees: as organisations seek to optimise employee output and employees make work meaningful to them (Hlatywayo, Mlanga \& Zingwe, 2014; Uppal, Mishra \& Vohra, 2014). 
Job stress poses as a great challenge and threat to an individual's psychological, physical as well as organisational health. When stress elements cross over and spill into one's family life it results in negative influences to an individual's wellbeing. Stress has caused many problems (Yahaya, Yahaya, Tamyes, Ismail \& Jaalam, 2010; Hlatywayo et al., 2014) especially on organisational performance. Scholars on stress concur on the difficulty for one to fully perform their job requirements when they have psychological issues to deal with (Pinkerton, 2003).

Is sues which lead to, and the cause for discomfort, need to be identified in time and dealt with. It is of vital importance for organisations to deeply apprehend issues concerning job stress since they carry great value for an economy's sustainability in terms of organisations, institutions and the wellbeing of people (Eby, Casper, Lockwood, Bordeaux \& Brinley, 2002). The study sought to explore on job stress and how it affects the organisational commitment of employees.

\section{LITERATURE REVIEW}

The effect of high stress levels is low organizational commitment, the spillover effects being voluntarily employee turnover and reduced organisation performance (Cicei, 2012; Gayathiri \& Ramakrishnan, 2014). Job related stress is one of the most common work related health problems (Javed, Balouch \& Hassan, (2014); Gayathiri \& Ramakrishnan, 2014). Lu, Cooper, Kao and Zhou, (2003) also agree that one of the current wellbeing issues is job stress. Stress carries harmful effects on employees (psychologically and physically) and it also contributes greatly to turnover and absenteeism, among other reasons Marine, Ruatsalaian, Serra and Verbeek, (2006) findings showed that job stress is triggered by various stres s conditions that employees operate under in their workplace. The ways these stressors affect an individual however depend on individual coping mechanis ms at a more personal level (Monteiro, Balogun \& Oratile, 2014; Cooper, Dewe \& O’Driscoll, 2001; Schaufeli \& Bunk, 2003). The health care sector is one of the main sectors in any country, and this sector is exposed to extensive work stress. Employees have to work sometimes for very long hours and when they get home from work, they are too exhausted and experience fatigue from the day's proceedings at work (Akintayo, 2010; Radcliffe \& Lester, 2003).

Literature has shown the existing relationship between job stress and organis ationalcommitment to be negative. These sentiments are echoed in Noor (2002). The strength of these results supports the notion proposed that job stress indeed has a relationship with work family conflict and organisationalcommitment. Stress is linked with reduced efficiency at work, diminished job fulfilment and decreased commitment to one's job or organisation resulting in intentions to quit the organis ation or the job.

\section{Job Stress and Affective Commitment}

Affective commitment refers to an emotional bond that an individual develops towards the organis ation. Employees who exhibit high levels of affective commitment have been found to experience low job stress levels (Namasivayam \& Zhao, 2007; Madi, Abu-Jarad \& Alqahtani, 2012). Such employees carry a great desire within them to be part of the organisation and as a result are more likely to enjoy their job thereby experiencing low stress levels regardless of how stressfuland hectic the conditions may be (Williams, 2010; Dixit \& Bhati, (2012). Individuals with low levels of affective commitment are more likely to be at risk for high stress levels arising from the work because such individuals tend to focus on negative aspects of the job. Affective commitment has been ascribed to be reducing the salience of role stress ors (Glazer \& Kruse, 2008).

\section{Job Stress and Continuance Commitment}

Continuance commitment is that type of commitment where people stay with the organisation because they feel they will lose much if they opt to leave (Dixit \& Bhati, 2012). It has to do with an individual's awareness of the costs associated with leaving the organisation (Meyer, Stanley, Herscovitch \& Topolnytsky, 2002; Madi et al., 2012). Employees with continuance commitment cannot be relied on to willingly contribute positively towards the organisation (Cohen, 2007). Such individuals have been found to report feelings of resentment and dissatisfaction because they feel trapped in their work with no better option (Namasivayam \& Zhao, 2007) and as a result experience high levels of stress. 


\section{Job Stress and Normative Commitment}

Normative commitment refers to a perceived responsibility to stay with the organisation (Meyer et al., 2002; Madi, et al., 2012). According to Herscovitch and Meyer (2002), cultural processes have an influence on this type of commitment. Most employees feel the obligation to stay with an organisation if it has invested greatly in them. Individuals with high levels of normative commitment stay with an organisation because they feel indebted to do so, hence such individuals focus more on the benefits they receive and pay less attention to the stressors in the workplace (Buonocore \& Russo, 2013).

\section{STUDY OBJECTIVE}

The objective of the study was to explore the impact of job stress on the components of commitment among public sector health care personnel.

\section{Hypothesis}

The following hypotheses were deduced from the above objective:

$\mathbf{H}_{\mathbf{1}}$ : There is a significant relationship between job stress and affective commitment.

$\mathbf{H}_{2}$ : There is a significant relationship between job stress and continuance commitment.

H3: There is a significant relationship between job stress and normative commitment.

\section{RESEARCH METHODOLOGY}

The research adopted a quantitative approach. The population consisted of employees from the selected hospitals in the Health Department in Nkonkobe Municipality, Eastern Cape South Africa. Cluster sampling was proposed to select the hospitals and the simple random sampling was to be used to select the sample from the hospitals. However, convenience sampling was used as the study instrument was handed to employees present when the study was conducted. A total of 180 questionnaires were distributed, of these 141 usable for the study indicating a response rate of $78 \%$.

The State Anxiety Inventory (SAI) by Speilberger, Gorsuch and Lushene (1969) was used for measuring stress and the 15-item Organisational Commitment Questionnaire (OCQ) developed by Mowday, Steers and Porter (1979) to measure organisational commitment. The Cronbach's alpha coefficient for the stress questionnaire recorded a reliability coefficient was 0.84 while with the organisational commitment, 0.76 . These results of the studies show that the instrument was reliable. Statistical Analysis Software (SAS 9.1) was used for data analysis. The Pearson Correlation Analysis was used to test the relationship between job stress and organisational commitment. All ethical matters were fully addressed and consent was obtained from the relevant authority

\section{RESULTS}

Of the 141 respondents, 85 were female and 56 males. Most of the respondents were 30 years and older and had been in the profession for at least a year and more. Most of the respondents had at least one child or more and $83 \%$ of the respondents had family responsibilities. Of the respondents, $90 \%$ work for more than 8 hours a day and $55 \%$ are the sole supporters for their families 
Table 1. Demographic variables

\begin{tabular}{|c|c|c|}
\hline Variable & Frequency & Percentage \\
\hline \multicolumn{3}{|l|}{ Gender } \\
\hline Male & 56 & 40 \\
\hline Female & 85 & 60 \\
\hline \multicolumn{3}{|l|}{ Age } \\
\hline $21-30$ & 32 & 22.7 \\
\hline $31-41$ & 60 & 42.6 \\
\hline $41-50$ & 37 & 26.2 \\
\hline $51-60$ & 11 & 7.8 \\
\hline $60+$ & 1 & 1 \\
\hline \multicolumn{3}{|l|}{ Family responsibility } \\
\hline Yes & 24 & 17 \\
\hline No & 117 & 83 \\
\hline \multicolumn{3}{|l|}{ Working hours } \\
\hline 8-hours & 14 & 10 \\
\hline$>8$-hours & 217 & 90 \\
\hline \multicolumn{3}{|l|}{ Sole supporter } \\
\hline No & 61 & 45 \\
\hline Yes & 76 & 55 \\
\hline \multicolumn{3}{|l|}{ Tenure } \\
\hline$<1$ year & 34 & 24.1 \\
\hline $1-5$ years & 57 & 40.4 \\
\hline $6-10$ years & 34 & 24.1 \\
\hline$<10$ years & 16 & 11.4 \\
\hline \multicolumn{3}{|l|}{ No. of children } \\
\hline 0 & 26 & 18.4 \\
\hline 1 & 30 & 21.4 \\
\hline 2 & 48 & 34.3 \\
\hline 3 & 21 & 15.1 \\
\hline 4 & 16 & 11.4 \\
\hline
\end{tabular}

\section{Hypotheses Testing}

Table 2 Pearson Correlation Coefficients, $\mathrm{N}=141$ Prob $>|\mathrm{r}|$ under $\mathrm{H} 0$ : Rho=0

\begin{tabular}{c|c|c|c}
\hline Job stress & Affective commitment & Continuance commitment & Normative commitment \\
\hline & 0.14001 & 0.13010 & -0.04696 \\
\hline & 0.977 & 0.1241 & 0.5803 \\
\hline
\end{tabular}

$\mathrm{H}_{1}$ sought to test for a significant relationship between job stress and affective commitment. As shown in table 2 above, a significant positive relationship exists between job stress and affective commitment ( $\mathrm{r}=0.14001$; 0.0977$)$. Therefore, the null hypothesis was accepted and the alternative hypothesis rejected.

$\mathrm{H}_{2}$ tested for a significant relationship between job stress and continuance commitment. The results found a positive but insignificant relationship between job stress and continuance commitment ( $r=0.13010$; 0.1241). As a result, the alternative hypothesis was accepted and the null hypothesis rejected. These results suggest that job stress has insignificant effects on continuance commitment.

H3 looked for a statistically significant relationship between job stress and normative commitment. The results from the study show that there is a negative but insignificant relationship between job stress and normative commitment ( $\mathrm{r}=-0.04696 ; 0.5803)$. 


\section{DISCUSSION}

The results showed that there is a relationship between job stress and organis ational commitment components. Cicei, (2012) study on the Romanian public service observed medium and high levels of stress and low and medium levels of organizational commitment. Cicei, (2012) found a strongly negatively associating with occupational stress and affective and continuance commitment. Jamal, (2011) compared job stress, job performance and organizational commitment in Pakistan and Malaysia using hierarchical multiple regression, organizational commitment moderated between stress and performance relationship. In the two countries, his data supported a negative linear relationship between stress and performance as compared to other relationship.

Job stress reported a positive impact on affective commitment meaning the individuals with high affective commitment are the ones who also reported high job stress levels. This is contrary to other research findings of (Williams, 2010; Glazer \& Kruse, 2008) who argued that individuals with high affective commitment exhibit lower stress levels. Rather in this case, individuals who have high levels of affective commitment reported high stress levels. This can be attributed to the fact that though they may have emotional attachments with the organisations, they also have emotional attachments with their family and personal roles and when these work roles continue to get in the way of family, stress can be inevitable even though they are attached to the organisation.

The results also indicated for a strong but insignificant relationship between job stress and continuance commitment. These results show that individuals who have high levels of continuance commitment experience high levels of job stress. Namasivayam and Zhao, (2007); Cohen, (2007) findings concur with the study findings. This is due to individuals in this category stay in the organisation because they have no better option and they feel trapped in the organisation. As a result, their focus falls easily on all the negatives and shortcomings of the job and the work conditions thereby being subject to much stress.

The results show also that job stress is negatively related to normative commitment implying that the higher the normative commitment in an individual, the lower the job stress levels. This is consistent to Buonocore and Russo (2013) who supports that the reason why individuals with high levels of normative commitment experience lower levels of job stress is because they focus more on the benefits they receive from the company and pay little or no attention to potential stressors within the workplace.

\section{CONCLUSIONS, RECOMMENDATIONS AND LIMITATIONS OF THE STUDY}

From the findings, job stres s carried a negative impact on organis ational commitment. Out of the three components of organisational commitment, only individuals who have high levels of normative commitment are not negatively affected by the effects of job stress. Individuals with high levels of affective and continuance commitment showed that as job stress increases, they also cannot withstand the stress and are victims of job stress. It is therefore important for the management in organisations to identify ways of making the workplace a better and more favourable place for employees as the working conditions contribute greatly to the emergence of stress within the employees. This can be done by implementing programs that encourage career and personal development to increase emotional commitment in employees hence reducing job stress and encouraging commitment at the same time. The research was however limited to a district in the Eastern Cape community which cannot fully represent the different diverse groups within South Africa and the world. The findings of the study are relevant to a global context as most developing and underdeveloped nations have characteristics similar to the selected district in the Eastern Cape.

For future research the researchers propose testing the study variables to a larger sample and add turnover intention as health care personnel in public health care facilities play a crucial role to the greater South African populous.

\section{AUTHOR BIOGRAPHIES}

Vongai Sarah Ruzungunde is a Ph.D. candidate in the department of Industrial Psychology at the University of Fort Hare. Her area of specialization include career development, occupational stress, work family conflict, personality, and work family conflict in the mining sector. E-mail: ruzungundev@gmail.com 
Chan Murugan is a Senior lecturer in the Department of Industrial Psychology at the University of Fort Hare. His research interests among others include career psychology, social psychology and employee and health. E-mail: cmurugan@ufh.ac.za

Clifford K. Hlatywayo is a researcher in the Department of Industrial Psychology at the university of Fort Hare. The authors' research interests are employability, career success, health and safety, competency development, training and development, organization psychology and workplace dynamics. E-mail: vakendie@gmail.com

\section{REFERENCES}

Akintayo, D. I. (2010). Work-family conflict and organisation commitment among industrial workers in Nigeria. Journal of Psychology and counselling, 2 (1), 1-8.http://www.academicjournals.org (Accessed online on 6 November 2013).

Bakker, A.B. \& Leiter, M.P. (2010). Employee Engagement: A handbook of Essential Theoryand Research. Psychology Press.

Buonocore, F. \& Russo, M. (2013). 'Reducing the effects of work-family conflict on job satisfaction: The kind of commitment matters'. Human Resources Management Journal, 23(1), 91-108.

Cicei, C.C. (2012). Occupational stress and organizational commitment in Romanian public organizations. Procedia - Social and Behavioral Sciences, 33, 1077 - 1081.

Cohen, A. (2007). Commitment before and after: A reconceptualization of organisational commitment. Human Resource Management, 17(6), 336-354.

Cooper, C.L., Dewe, P. \& O’Driscoll M.P. (2001). Organisational stress. London: Sage.

Crouter, A.C., Head, M.R., McHale, S.M. \& Tucker, C.J. (2004). Family time and the adolescent siblings and their parents. Journal of Marriage and Family, 66, 147-162.

Dixit, V. \& Bhati, M. (2012). A Study about Employee Commitment and its impact on Sustained Productivity in Indian AutoComponent Industry European Journal of Business and Social Sciences, 1(6), 34 - 51.

Eby, L.T., Casper W.J., Lockwood, A., Bordeaux, C. \& Brinley, A. (2002). Work and family research in IO/OB: Content analy sis and review of the literature (1980-2002) Journal of Vocational Behavior, 60, 354-373.

Gayathiri, R. \& Ramakrishnan, L. (2014). Quality of Work Life - Linkage with Job Satisfaction and Performance. International Journal of Business and Management Invention, 2(1), 1-8.

Glazer, S. \& Kruse, B. (2008). 'The role of organisational commitment in occupational stress models'. International Journal of Stress Management, 15(4), 329-344.

Hall, E.J. (2004). Nursing attrition and the work environment in South African health facilities. Curationis, 2 7(4), 29-36.

Hlatywayo, C. K.. Mlanga, T.S. \& Zingwe, T. (2014). Precursors of Emotional Stability, Stress and Work-Family Conflict among Female Bank Employees International Business \& Economics Research Journal. 13 (4), 861-866.

Herscovitch, L. \& Meyer, J.P. (2002). Commitment to organisational change: Extension of a three component model, Journal of Applied Psychology, 87, 474-487.

Iqbal, S., Ehsan, S., Rizwan, M.\& Noreen, M. (2012). The impact of organizational commitment, job satisfaction, job stress and leadership support on turnover intention in educational institutes. International Journal of Human Resource Studies, 4(2) 181-195.

Jamal, M. (2011). Job Stress, Job Performance and Organizational Commitment in a Multinational Company: An Empirical Study in two Countries. International Journal of Business and Social Science, 220; 20-29.

Jamal, M. (2005). Burnout among Canadian and Chinese employees: A cross-cultural study. European Management Review, 2 , 224-230.

Javed, M., Balouch, R. \& Hassan, F. (2014). Determinants of Job Satisfaction and its Impact on Employee Performance and Turnover Intentions. International Journal of Learning \& Development 4(2), 120-140.

Lu, L., Cooper, C.L., Kao, S.F. \& Zhou, Y. (2003). Work stress, control beliefs and well- being in Greater China - An exploration of sub-cultural differences between the PRC and Taiwan, Journal of Managerial Psychology, 18(6), 479.

Madi, M., Abu-Jarad, I. \& Alqahtani, A, H, M (2012). Employees' Perception and Organizational Commitment: A Study on the Banking Sector in Gaza, Palestine. International Journal of Business and Social Science, 3(16), 299-312.

Marine, A., Ruatsalaian, J., Serra, C. \& Verbeek, J. (2006). Preventing occupational stress in healthcare workers (Review), John Wiley \& Sons Ltd. http://www.thecochranelibrary.com(Accessed online on 6 November 2013).

McNeely, E. (2005). The consequences of job stress for nurses' health: Time for a check-up. Nursing Outlook; 53:291-299.

Meyer, J.P., Stanley, D.J., Herscovitch, L. \& Topolnytsky, L. (2002). Affective, continuance, and normative commitment to the organisation: A meta-analysis of antecedents, correlates, and consequences. Journal of Vocational Behavior, 61(1), $20-52$.

Monteiro, N.M., Balogun, S.K. \& Oratile, K. N. (2014). Managing stress: the influence of gender, age and emotion regulation on coping among university students in Botswana. Int J Adolescent Youth. 19(2), 153-173.

Mowday, R.T., Steers, R.M. \& Porter, L.W. (1979). The Measurement of Organisational Commitment. Journal of Vocational Behavior, 14, 224-247. 
Namasivay am, K. \& Zhao, X. (2007). 'An investigation of the moderating effects of organizational commitment on the relationships between work-family conflict and job satisfaction among hospitality employees in India'. Tourism Management, 28(5), 1212-1223.

Nomaguchi, K.M. (2009). Change in work-family conflict among employed parents between1977 and 1997. Journal of Marriage and Family, 71, 15-32.

Noor, N.M. (2002). The Moderating Effect of Spouse Support on the Relationship between Work Variables and Women's Work-Family Conflict, 'Psychologia: An International Journal of Psychology in the Orient, 45(1), 12-23.

Pinkerton, S. (2003). Recruitment and retention: mentoring new graduates, Nursing Economics, 21(4), $202-203$.

Radcliffe, C. \& Lester, H. (2003). Perceived stress during undergraduate medical training: A Qualitative study, Med Edu 37(1), 32-38.

Robbins, E. \& Sanghi, M. (2006). Organisational Behavior. (1 ${ }^{\text {th }}$ Ed.), India: Dorling Kindersley.

Schaufeli, W.B. \& Bunk, B.P. (2003). Burnout: An Overview of 25 Years of Research and Theorizing. In: Schabracq, M.J., Winnubst J.A.M. \& Cooper, C.L. editor(s). The handbook of Work and Health Psychology. (2 ${ }^{\text {nd }}$ ed). Chichester: Wiley, 383-424.

Speilberger, C.D., Gorsuch, R. \& Lushen, R. (1969). State-trait anxiety inventory, preliminary test manual. Counselling Psychologists Press

Uppal, N., Mishra, S.K. \& Vohra, N. (2014). Prior related Work Experience and job performance: Role of Personality. International Journal of Selection and Assessment, 22 (1) 39-51.

Williams, R. (2010). 'Does affective commitment decrease the level of stress reported in teachers? A comparison of primary and secondary school teachers'. The Plymouth Student Scientist, 3 (2), 142-163.

Yahay a, N., Yahaya, A., Tamyes, F.A., Ismail, J. \& Jaalam, S. (2010). The Effect of Various Modes of Occupational Stress, Job Satisfaction, Intention to Leave and Abseentism Companies Commission of Malaysia, Australian Journal of Basic and Applied Sciences, 4(7),1676-1679.

Yahaya, A., Yahaya, N., Ma'alip, H., Ramli, J., \& Kamal, M.M.(2012). The Relationship Between the Occupational Stress, Organizational Commitment, and Job Satisfaction With Organizational Citizenship Behavior. Archives Des Sciences, 65(3) 55-73. 


\section{NOTES}

